$$
\text { MT-DP - 2010/12 }
$$

\title{
Asymmetric Competition in the Setting of Diesel Excise Taxes in EU Countries
}

LÁSZLÓ PAIZS 


\section{Discussion papers}

MT-DP - 2010/12

Institute of Economics, Hungarian Academy of Sciences

KTI/IE Discussion Papers are circulated to promote discussion and provoque comments. Any references to discussion papers should clearly state that the paper is preliminary. Materials published in this series may subject to further publication.

Asymmetric Competition in the Setting of Diesel Excise Taxes in EU Countries

Author:

László Paizs

research fellow

Insitute of Economics of Hungarian Academy of Sciences

E-mail:paizs@econ.core.hu

June 2010

ISBN $978 \quad 615 \quad 5024 \quad 01 \quad 6$

ISSN $1785377 \mathrm{X}$ 


\title{
Asymmetric Competition in the Setting of Diesel Excise Taxes in EU Countries
}

\author{
László Paizs
}

\begin{abstract}
This paper tests new implications of the asymmetric tax competition model on diesel excise taxes in the European Union (EU). I extend the standard tax competition model by replacing the unit demand assumption with iso-elastic demand. As a result, not only the level of the equilibrium tax but also the slope of the tax reaction function depends positively on the size of the country. The new implication is testable on panel data in first differences, and it is tested on a panel of 16 European countries. The results provide strong evidence for strategic interaction in the setting of diesel excises and confirm the effect of country size on the response to tax changes in neighboring countries. Strategic interaction between EU countries intensified in the mid 1990s and drove small European countries to set lower diesel tax rates. These results explain why the EU's minimum tax policy has failed to harmonize diesel tax rates across member states.
\end{abstract}

Keywords: tax competition, minimum tax, asymmetric regions, diesel excise, European Union

JEL: H70, H77, H87

\section{Acknowledgement:}

I would like to express my gratitude to Gábor Kézdi for his encouragement and generous support during the course of this work. I also thank Péter Kaderják, Gábor Koltay, Marianna Kopasz, Tamás Meszerics, Pál Valentiny, Hendrik Vrijburg and the participants at the 63rd Congress of the IIPF, Warwick, at the 2007 Labsi International Conference, Siena, at the 2007 annual conference of the Hungarian Society of Economics, Budapest, at the research day of the Institute of Economics of the Hungarian Academy of Sciences, Budapest, 2008, for helpful comments and discussions. This research was supported by a grant from the CERGE-EI Foundation under a program of the Global Development Network. All opinions expressed are those of the author and have not been endorsed by CERGE-EI or the GDN. 


\title{
Aszimmetrikus adóverseny az EU tagállamok gázolaj jövedéki adójában
}

\author{
PAIZS LÁSZLÓ
}

\section{Összefoglaló}

Jelen tanulmány egy új adóverseny hipotézist tesztel az Európai Unió tagországainak gázolajra kivetett jövedéki adókulcsain. A standard két országos adóverseny modelltől eltérően a kis és nagy ország közötti adóversenyt árrugalmas fogyasztói kereslet mellett vizsgálom. Megmutatom, hogy amikor a kereslet árrugalmas, akkor egy ország relatív mérete nemcsak az egyensúlyi adókulcsára, hanem adó reakciófüggvényének meredekségére is pozitív hatással van. Az első-differenciákra felírt adó reakciófüggvény-egyenlet becsléséhez 16 európai ország 1978 és 2005 közötti gázolaj jövedéki adókulcs adatait használom. Az empirikus eredmények alátámasztják az adóversenyre vonatkozó hipotézist és megerősítik a tanulmány fő hipotézisét is, mely szerint a nagyobb országok nagyobb erővel reagálnak szomszédaik adóváltoztatására, mint kisebb társaik. Arra is bizonyítékot találok, hogy a tagországok közötti stratégiai interakciók felerősödnek az 1990-es évek közepétől, ami ez előbbi eredményekkel együtt megmagyarázza, hogy miért kezdtek el a kisebb tagállamok ettől az időszaktól kezdve nagyobb szomszédaiknál rendre alacsonyabb adókulcsot megállapítani, és hogy miért nem sikerült a minimumadó-szint előírása révén az Európai Uniónak harmonizáltabb jövedéki adóztatást teremtenie.

Tárgyszavak: adóverseny, minimumadó, aszimmetrikus régiók, gázolaj jövedéki adó, Európai Unió

JEL kód: H70, H77, H87 


\section{INTRODUCTION}

Excise taxes on diesel fuel are likely to be subject to tax competition in the European Union for several reasons. There is an incentive for consumers to buy diesel in countries where the tax burden on fuel is lower. The incentive for fuel tourism is magnified by the fact that the largest consumers of diesel are commercial carriers (trucks and buses), whose fuel bill accounts for about 15 to 30 percent of total operating costs. The large asymmetry between European countries in terms of size can also increase tax competition. According to Kanbur and Keen's (1993) and Wilson's (1991) analysis of asymmetric tax competition, small jurisdictions should set lower tax rates than large jurisdictions, and they can benefit substantially from tax competition if differences between jurisdictions are sufficiently large. ${ }^{1}$

The pattern of diesel tax rates and the available evidence on cross-border fuel shopping in EU countries are broadly consistent with the above argument. Small European countries (in terms of territory or GDP) tend to levy lower excise rates on diesel than large countries. In 2005, the diesel excise tax in small-sized countries was 15 percent lower on average than in the large countries in the European Union. There is also some evidence that tax-induced crossborder shopping for diesel is occurring on a large scale at some borders. For example, in Germany where diesel is more expensive than in neighboring countries due to higher excise duties, 10 percent of all domestically consumed diesel was cross-border shopped in 2004, implying a tax revenue loss of 2 billon euros to the German Treasury (Commission of the European Communities, 2007). On the other hand, in Austria where diesel is relatively cheap, some 30 percent of fuel purchases on the domestic market is due to fuel tourism from neighboring countries (Austrian Energy Agency, 2009).

Motivated by the above observations, this paper seeks to assess the importance of tax competition in the setting of diesel excise taxes among European countries. I extend Nielsen's (2001) model of asymmetric tax competition to allow for the demand for the taxed good to have nonzero elasticity. The model retains Nielsen's implication that smaller countries should set lower taxes. A novel implication is that the size of a country positively influences the slope of its reaction function as well, so that the reaction of larger countries should be stronger. This result has important implications for the empirical analysis as it is testable on panel data in first differences.

The main contribution of the paper is empirical, and it fits in the literature of strategic interactions in fiscal policy initiated by Case et al. (1993). I use panel data of diesel excise tax rates from 16 European countries between 1978 and 2005. I estimate standard tax-competition

\footnotetext{
${ }^{1}$ In fact, Kanbur and Keen (1993) show that for any high pre-competition level of the tax rate there exists a big size difference between the two countries that the small country would be better off with the tax competition outcome (Kanbur and Keen, 1993).
} 
regressions with countries' tax rate on the left hand side and a weighted average of the neighbors' (lagged) tax rates on the right hand side, along of course with other control variables.

The analysis contributes to the existing literature in a number of ways. Firstly, in line with my theoretical prediction, I augment the reaction function equation with an interaction term between foreign tax rates and country size in order to capture the effect of country size on its slope.

Secondly, the regressions are estimated in first differences in order to control for unobserved country fixed effects and ensure stationarity (tax rates trend upwards in the sample). Testing in first differences is possible because the extended theoretical model yields the same prediction for changes as for levels. My third contribution is a careful treatment of endogeneity. While first differencing, together with lagging the neighbors' tax variables, can reduce the role of omitted variables, common shocks may still lead to inconsistent results if they are serially correlated. The typical approach is to instrument the neighbors' tax rates with their macroeconomic and political characteristics. One potential criticism of using macroeconomic instruments is that the economic conditions of neighboring countries are likely to be correlated because of some synchronization of business cycles. In order to address this concern I restrict the instruments to include political covariates only. I also add the spatial lag of the tax rate to the instruments. The two sets of instruments lead to the same qualitative conclusions if entered separately, but their joint use ensures that the instruments are sufficiently strong. The final contribution of this paper is that it uses a novel weighting scheme based on the levels of commercial traffic at the border crossings of neighboring countries. This weighting scheme is designed to reflect the assumption that the tax base that countries may be competing over consists primarily of the diesel purchases by truck drivers. The weights are likely to be predetermined, but I cross-check the results with more conventional weights in order to show their robustness to potential endogeneity in the weighting scheme.

The main findings of the analysis are as follows. First, I find evidence for tax competition in diesel excises between European countries in the period 1978 to 2005. My estimation shows that 10 percent increase in the neighbors' excise tax rates on diesel induces a 2.5 percent increase in a country's diesel excise rate. Second, consistent with the extended model of tax competition with demand elasticity between $\mathrm{o}$ and 1 in absolute value, I find strong evidence that country sizes affect the slope of the reaction function. The estimation shows that in response to a 10 percent increase in neighboring countries' diesel tax rates, an average large country raises its tax rate by 4.4 percent while an average small country increases its tax rate only by 1.3 percent. Third, I show that strategic interaction in the setting of diesel excises intensified since the mid 1990s. These results are supportive of the view that it is the process of asymmetric tax competition that drives small European countries to set lower tax rates than 
their larger neighbors since 1995. Therefore, asymmetric tax competition can explain why the EU's minimum tax policy adopted in 1993 has failed to harmonize diesel tax rates across member states.

The reminder of this paper is organized as follows. Section 2 provides a theoretical framework for the empirical analysis. Section 3 elaborates the econometric model, discusses the main issues in estimation and presents the data. Section 4 discusses the empirical results. Section 5 assesses the performance of the EU's minimum tax rate policy. Finally, Section 6 concludes with some policy implication of my results.

\section{THE MODEL}

I construct a simple theoretical model to analyze the tax setting behavior of national governments faced with cross-border shopping at their borders. The model is an extension of Nielsen (2001) to allow for elastic individual demand for the taxed good. This extension is motivated with an eye on the empirical test in first differences and it is consistent with the general notion that the demand for motor fuels is responsive to prices. Empirical works show that the short-run elasticity of motor fuel is in the range of -0.2 and -0.3 while the same numbers for the long-run elasticity are in between -0.6 and -0.8 (Fulton and Noland, 2005). ${ }^{2}$

\footnotetext{
${ }^{2}$ My theoretical analysis was partly inspired by the study of Devereux et al. (2007). Devereux et al. (2007) examine the commodity tax competition of gasoline and cigarettes in the US, theoretically and empirically. The authors simultaneously integrate and generalize previous theoretical works by examining horizontal and vertical tax competition (i) in a unified theoretical framework, (ii) allowing for countries to differ both in area and in population density, and (iii) assuming price elastic demand. From this general theoretical framework the authors establish that the horizontal reaction functions of the two countries are positively sloped. By considering a less generalized model, allowing the demand to be price elastic, but conceptualizing spatial differences of countries only according to their area and focusing only on horizontal interactions, we are able to give a more accurate characterization of the outcome of tax competition.
} 


\subsection{THE BASIC SETUP}

Consider two countries $\left({ }^{i=1,2}\right)$ that lie on the interval $[-1 ; 1]$ with a border between them at $b$. In both countries residents are spread evenly by unit density. The population of each country thus corresponds to its linear extensions: $(1+b)$ and $(1-b)$, respectively. The larger $b$ is, the larger being the difference in size between the two countries. In each country the government imposes a specific tax $\tau_{i}$ on the same commodity (e.g. motor diesel). For simplicity, the production cost of the commodity is assumed to be zero ( $p_{i}=0$ for $i=1,2$ ). The consumer price of the commodity in each country is thus equal to the tax charged.

Consumers may purchase the commodity in one of the following two ways: (1) the consumer can buy the good at her doorstep or (2) the consumer can cross-border shop for the commodity. In the latter case, the consumer has to travel to the border, incurring travel cost. I assume that traveling to the border (and back) entails a cost of $d$ per unit of distance travelled.

Up to this point the setup is equivalent to that of Nielsen (2001). From now on I depart from his model by allowing the demand for the taxed good to be price elastic. In Nielsen's model, each resident purchases one unit of the good irrespective of its price, i.e. the demand for the good is perfectly inelastic $(x(\tau)=1)$. Instead, I assume that consumers have an isoelastic demand function $\left(x(\tau)=\tau^{\varepsilon}\right.$ ) with price elasticity $-1<\varepsilon \leq 0$. Note that when individual demand is perfectly inelastic, that is $\varepsilon=0$, the model reduces to the Nielsen (2001) model.

\subsection{THE NUMBER OF CROSS-BORDER SHOPPERS}

First, I derive the number of cross-border shoppers as a function of the level of taxes in country $i$ and $j$. Following Devereux et al. (2007), I assume that consumers have a quasi-linear utility function that depends on two goods, the numeraire and the taxed commodity. Suppose that $\tau_{i}>\tau_{j}$. An individual in country $i$ will shop cross-border if and only if her surplus by doing so $V\left(\tau_{j}, m-g d\right)$ exceeds the surplus from buying at home $V\left(\tau_{i}, m\right)$, where $g$ stands for the distance between her location and the border and $m$ denotes her total income. Therefore consumers in country $i$ will shop from country $j$ until: 
$-g d-\frac{1}{1+\varepsilon} \tau_{j}^{1+\varepsilon} \geq-\frac{1}{1+\varepsilon} \tau_{i}^{1+\varepsilon}$

By rearranging the above expression, one can determine the location of the marginal consumer $\left(g_{m}\right)$ who is indifferent to shopping in country $i$ or country $j$. This is

$g_{m}=\frac{1}{d(1+\varepsilon)}\left(\tau_{i}^{1+\varepsilon}-\tau_{j}^{1+\varepsilon}\right)$

Since consumers are uniformly distributed on $[-1 ; 1], g_{m}$ is also the number of residents in country $i$ who are shopping across the border for a given pair of $\tau_{i}$ and $\tau_{j}$.

\subsection{THE NASH EQUILIBRIUM}

Now I consider the government's problem. In each country the government is assumed to choose its own tax rate to maximize its tax revenue, taking as given the other country's tax rate and bearing in mind the impact of cross border shopping. Denoting the number of shoppers in country $i$ with $s_{i}\left(\tau_{i}, \tau_{j}\right)$, the tax base in country $i$ is $X_{i}\left(\tau_{i}, \tau_{j}\right)=s_{i}\left(\tau_{i}, \tau_{j}\right) x\left(\tau_{1}\right)$. Using the expression for the number of cross-border shoppers obtained in Eq. (1), the tax base for government in country 1 and country 2 (from now on the large country is denoted by 1 ) is then

$$
\begin{aligned}
& X_{1}\left(\tau_{1}, \tau_{2}\right)=s_{1}\left(\tau_{1}, \tau_{2}\right) x\left(\tau_{1}\right)=\left[1+b+\frac{1}{d(1+\varepsilon)}\left(\tau_{2}^{1+\varepsilon}-\tau_{1}^{1+\varepsilon}\right)\right] x\left(\tau_{1}\right) \\
& X_{2}\left(\tau_{1}, \tau_{2}\right)=s_{2}\left(\tau_{1}, \tau_{2}\right) x\left(\tau_{2}\right)=\left[1-b+\frac{1}{d(1+\varepsilon)}\left(\tau_{1}^{1+\varepsilon}-\tau_{2}^{1+\varepsilon}\right)\right] x\left(\tau_{2}\right) .
\end{aligned}
$$

Thus the tax revenue in country 1 and 2 is given by the following functions:

$$
\begin{aligned}
& R_{1}\left(\tau_{1}, \tau_{2}\right)=\left[1+b+\frac{1}{d(1+\varepsilon)}\left(\tau_{2}^{1+\varepsilon}-\tau_{1}^{1+\varepsilon}\right)\right] x\left(\tau_{1}\right) \tau_{1} \\
& R_{2}\left(\tau_{1}, \tau_{2}\right)=\left[1-b+\frac{1}{d(1+\varepsilon)}\left(\tau_{1}^{1+\varepsilon}-\tau_{2}^{1+\varepsilon}\right)\right] x\left(\tau_{2}\right) \tau_{2} .
\end{aligned}
$$

Revenue maximization results in the following tax reaction functions: 
$r_{1}\left(\tau_{2}\right)=\left[\frac{(1+\varepsilon) d(1+b)}{2}+\frac{1}{2} \tau_{2}^{1+\varepsilon}\right]^{\frac{1}{1+\varepsilon}}$ and $\quad r_{2}\left(\tau_{1}\right)=\left[\frac{(1+\varepsilon) d(1-b)}{2}+\frac{1}{2} \tau_{1}^{1+\varepsilon}\right]^{\frac{1}{1+\varepsilon}}$

By solving the above equation system for $\tau_{1}$ and $\tau_{2}$, we receive the Nash equilibrium taxes of the game:

$\tau_{1}^{*}=\left[(1+\varepsilon) d\left(1+\frac{b}{3}\right)\right]^{\frac{1}{1+\varepsilon}} \quad$ and $\quad \tau_{2}^{*}=\left[(1+\varepsilon) d\left(1-\frac{b}{3}\right)\right]^{\frac{1}{1+\varepsilon}}$

From Eq. (5) we can establish that the small country levies a lower tax rate in the equilibrium than does the large country. It also follows that the difference between those tax rates increases as the disparity in size between the two countries increases (i.e. as $b$ increases). Nielsen's (2001) main finding extends to the class of constant elasticity demand functions with elasticity less than one.

\subsection{THE REACTION FUNCTIONS}

In order to give a more precise characterization of the governments' equilibrium behavior, let's turn to the properties of the tax reaction functions. Taking the first derivatives of the reaction functions with respect to $\tau_{1}$ and $\tau_{2}$, we obtain that

$$
\begin{aligned}
& \frac{d r_{1}}{d \tau_{2}}=\frac{1}{2} \tau_{2}^{\varepsilon}\left[\frac{(1+\varepsilon) d(1+b)}{2}+\frac{1}{2} \tau_{2}^{1+\varepsilon}\right]^{\frac{-\varepsilon}{1+\varepsilon}}>0 \\
& \frac{d r_{2}}{d \tau_{1}}=\frac{1}{2} \tau_{1}^{\varepsilon}\left[\frac{(1+\varepsilon) d(1-b)}{2}+\frac{1}{2} \tau_{1}^{1+\varepsilon}\right]^{\frac{-\varepsilon}{1+\varepsilon}}>0
\end{aligned}
$$

Eq. (6) shows that the reaction functions of the two countries are positively sloped: both countries raise its tax rate in response to an increase in the other country's tax rate. Further, in the special case when $\varepsilon=0$ and thereby $x\left(\tau_{1}\right)=x\left(\tau_{2}\right)=1$, i.e. in Nielsen's model (2001), the reaction functions are linear and their slopes are 0.5 . When the demand is not perfectly inelastic, that is when $-1<\varepsilon<0$, the reaction functions are concave because $\frac{d^{2} r_{1}}{d \tau_{2}^{2}}<0$ and $\frac{d^{2} r_{2}}{d \tau_{1}^{2}}<0$. From Eq. (6) it is also clear that $\left.\frac{d r_{1}}{d \tau_{2}}\right|_{\tau_{2}=\tau}>\left.\frac{d r_{2}}{d \tau_{1}}\right|_{\tau_{1}=\tau}$ for any positive $\tau$. This and the 
concavity of $r_{1}\left(\tau_{2}\right)$ and $r_{2}\left(\tau_{1}\right)$ imply that $\frac{d r_{1}}{d \tau_{2}}>\frac{d r_{2}}{d \tau_{1}}$ for any pair of $\tau_{1}$ and $\tau_{2}$ such that $\tau_{1}>\tau_{2}$. Evaluated at the Nash equilibrium, the ratio of the two slopes is the following:

$$
\frac{\left.\frac{d r_{1}}{d \tau_{2}}\right|_{\tau_{2}=\tau_{2}^{*}}}{\left.\frac{d r_{2}}{d \tau_{1}}\right|_{\tau_{1}=\tau_{1}^{*}}}=\frac{\frac{1}{2}\left(\frac{3+b}{3-b}\right)^{\frac{-\varepsilon}{1+\varepsilon}}}{\frac{1}{2}\left(\frac{3-b}{3+b}\right)^{\frac{-\varepsilon}{1+\varepsilon}}}=\left(\frac{3+b}{3-b}\right)^{\frac{-2 \varepsilon}{1+\varepsilon}}>1
$$

From Eq. (7) one can establish that the reaction function of the large country has a higher slope than that of the small country in the equilibrium when $-1<\varepsilon<0$. This means that the two countries have a different response to a change in the other country's tax rate. The large country responds more strongly to a change in its neighbor's tax rate than does the small country. This differential increases as the disparity in country size $b$ increases. ${ }^{3}$

To develop an intuition for this result, let's examine how the sensitivity of the tax base to the own tax rate compares in the two countries. Taking the first derivative of Eq. (2) with respect to $\tau_{i}$ at the Nash equilibrium, we obtain:

$$
\frac{d X_{i}}{d \tau_{i}}=\underbrace{s_{i}^{\prime}\left(\tau_{i}^{*}, \tau_{j}^{*}\right) x\left(\tau_{i}^{*}\right)}_{\text {migration-effect }}+\underbrace{s_{i}\left(\tau_{i}^{*}, \tau_{j}^{*}\right) x^{\prime}\left(\tau_{i}^{*}\right)}_{\text {demand -effect }}
$$

The above expression shows that a reduction in the domestic tax rate has two different effects on a country's tax base. First, it increases the country's tax base via increasing (or decreasing) the number of cross-border shoppers entering (leaving) the country. Second, it increases the country's tax base through increasing the per capita consumption of the taxed good in the country. The former may be regarded as the "migration effect" and the latter as the "demand effect" of a tax rate reduction. Let us first see how the migration effect of a tax change compares in the two countries. First note that in the small country where individuals purchase more of the taxed good, the effect of a marginal change in the tax rate on individual welfare is higher than it is in the large country. For this reason the number of shoppers in the small country is more sensitive to a change in domestic tax rate than in the large country $\left(-s_{1}^{\prime}\left(\tau_{1}^{*}, \tau_{2}^{*}\right)=\frac{1}{d} x\left(\tau_{1}^{*}\right)<-s_{2}^{\prime}\left(\tau_{1}^{*}, \tau_{2}^{*}\right)=\frac{1}{d} x\left(\tau_{2}^{*}\right)\right)$. This, in combination with higher per capita

3 This result is likely to extend to a wider class of demand functions than used here. For example I could derive the same results for the function of $x(\tau)=1 /(1+\tau)$, too. 
consumption in the small country, implies that the volume of cross-border purchases is more responsive with respect to the own tax rate in the small country than in the large country. Now let's turn to the demand effect of a tax rate reduction in the large versus the small country. For a marginal decrease in domestic tax rate, the small country experiences a higher increase in per capita consumption $\left(-x^{\prime}\left(\tau_{1}^{*}\right)<-x^{\prime}\left(\tau_{2}^{*}\right)\right)$, and although it has a smaller number of shoppers in the equilibrium than the large country does $\left(s_{1}\left(\tau_{1}^{*}, \tau_{2}^{*}\right)=\left(1+\frac{b}{3}\right)>s_{2}\left(\tau_{1}^{*}, \tau_{2}^{*}\right)=\left(1-\frac{b}{3}\right)\right)$, the overall effect on demand is greater for the small country as $-s_{1}\left(\tau_{1}^{*}, \tau_{2}^{*}\right) x^{\prime}\left(\tau_{1}^{*}\right)=-\varepsilon[(1+\varepsilon) d]^{\frac{\varepsilon-1}{\varepsilon+1}}\left(1+\frac{b}{3}\right)^{\frac{2 \varepsilon}{\varepsilon+1}}<-s_{2}\left(\tau_{1}^{*}, \tau_{2}^{*}\right) x^{\prime}\left(\tau_{2}^{*}\right)=-\varepsilon[(1+\varepsilon) d]^{\frac{\varepsilon-1}{\varepsilon+1}}\left(1-\frac{b}{3}\right)^{\frac{2 \varepsilon}{\varepsilon+1}} . \quad$ Thus we find that the total effect of a domestic tax cut on the tax base (including both the effects of migration and demand) is unambiguously greater for the small country than for the large country. In other words, the small country's tax base is more responsive with respect to a change in the own tax rate compared to the large country.

In the standard model, due to the assumption of unit demand, the responsiveness of the tax base to the own tax rate is identical in the two countries. This is why the two countries have the same response to a change in the other country's tax rate; i.e. the reaction functions of the two countries are equally sloped. In contrast, in the general model that allows for elastic individual demand, the responsiveness of the tax base to the own tax rate is different in the two countries with the small country facing a more elastic tax base. For this reason the small country has less incentive to raise its own tax rate when the foreign tax rate increases; i.e. its reaction function is less steep than that of the large country.

\subsection{SUMMARY OF HYPOTHESES}

Similar to the standard model, this more general model predicts that the tax rate set in a country is positively related to the tax rate set in the other country, and that country size has a positive impact on the tax rate chosen. This leads to the following hypotheses:

Hypothesis 1 A country's diesel tax rate is positively related to the diesel tax rates of its neighbors; i.e. the reaction functions are upward sloping.

Hypothesis 2 Countries that are small relative to their neighbors tend to set lower diesel tax rates. 
The novel finding from the extended model is that under price elastic demand country size also affects the slope of the reaction function. In the presence of price elastic demand, the small country faces a more elastic tax base and hence it reacts less intensively to changes in the other country's tax rate, compared to the large country. This leads to the main hypothesis of this paper:

Hypothesis 3 Small countries tend to respond less strongly to changes in their neighbors' diesel tax rates than large countries do; the small country's reaction function is less steep than that of the large country.

\section{Figure 1}

\section{Reactions functions in the standard and in the general model}

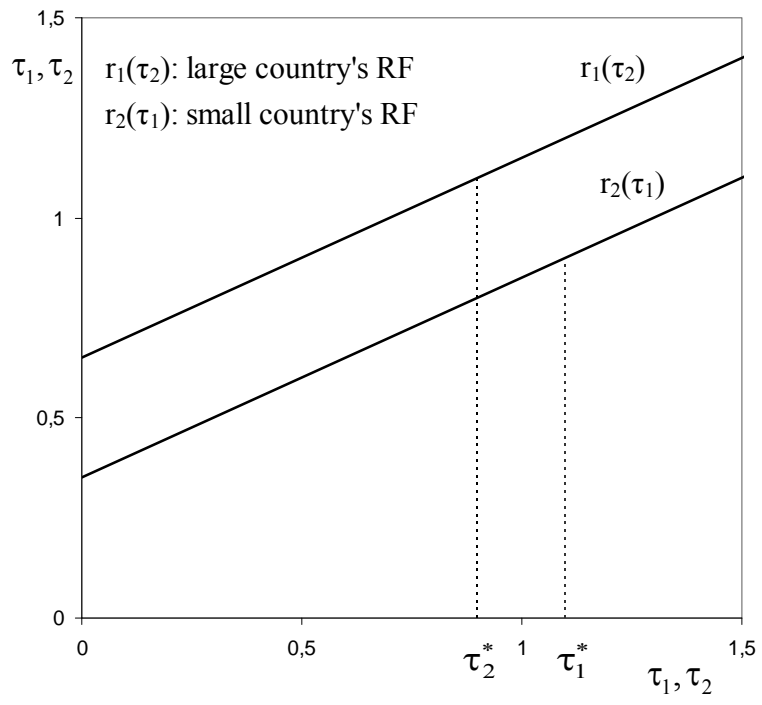

a, inelastic demand $(\varepsilon=0)$

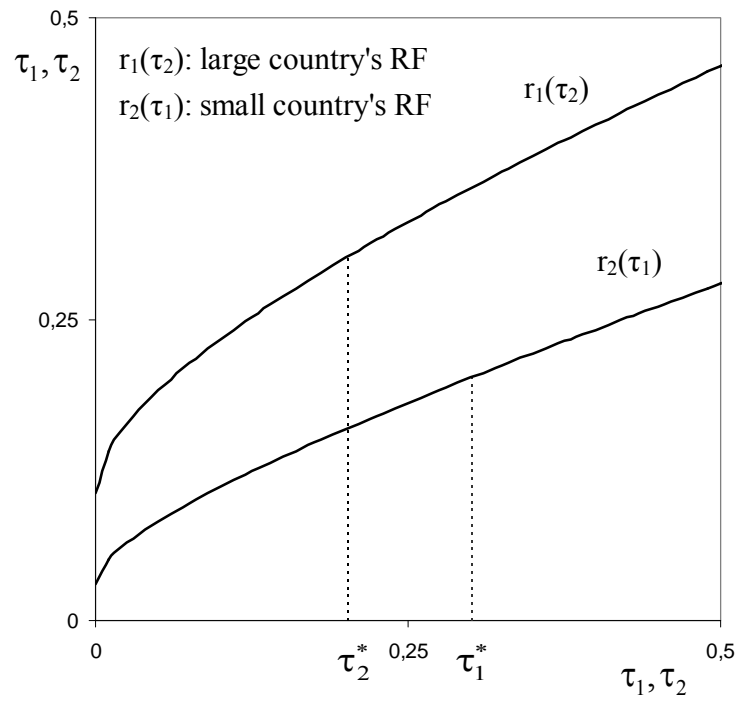

$\mathrm{b}$, iso-elastic demand $(-1<\varepsilon<0)$ 


\section{EMPIRICAL INVESTIGATION}

\subsection{THE ECONOMETRIC MODEL}

In this section I test the theory using a panel data set of excise tax rates from 16 European countries between 1978 and 2005. This is done by estimating tax reaction functions for national governments. The theoretical framework above suggests the following empirical specification for the reaction functions:

$\tau_{i t}=\alpha_{i}+\beta \sum_{j \neq i} \omega_{i j} \tau_{j t-1}+\delta \sum_{j \neq i} \omega_{i j} \tau_{j t-1} \cdot \operatorname{Size}_{i}+\operatorname{Size}_{i} \gamma+\theta X_{i t}+d_{t} \varphi+u_{i t}$

where $\tau_{i t}$ represents the diesel excise tax rate set by country $i$ in period $t, \alpha_{i}$ are timeinvariant unobserved country effects, $\omega_{i j}$ are a priori determined weights, Size ${ }_{i}$ denotes the time-invariant variable for the size of country $i, X_{i, t}$ is a vector of relevant characteristics of country $i$ in period $t$, and $d_{t}$ is a set of year dummies. The weights $\omega_{i j}$ are used to aggregate foreign tax rates (relevant to the decision of country $i$ ) into a single variable $\sum_{j \neq i} \omega_{i j} \tau_{j t-1}$, which is hereafter called as neighbors' tax rate. The $\omega_{i j}$ are normalized, so that $\sum_{j \neq i} \omega_{i j}=1$. In effect, each country is expected to react to the weighted average of the tax rates of its neighbors. I discuss the weighting schemes I use in the next section.

This specification is broadly consistent with the one used in other studies, except that my equation also incorporates an interaction term between neighbors' tax rate and country size. The inclusion of the interaction term follows from my theoretical model, which suggests that the effect of the neighbors' tax rates differ across countries according to their size. 
I have chosen to estimate the model in first-differences to account for the fact that diesel excise rates have been trending upward over the examined time period (see later). The panel unit root tests confirm that all the variables are stationary in their first-differences. Taking the first-differences of Eq. (8) gives

$$
\Delta \tau_{i t}=\beta \Delta \sum_{j \neq i} \omega_{i j} \tau_{j t-1}+\delta \Delta \sum_{j \neq i} \omega_{i j} \tau_{j t-1} \cdot \operatorname{Size}_{i}+\theta \Delta X_{i t}+d_{t} \varphi+u_{i t}
$$

Note that the unobserved country fixed effects $\alpha_{i}$ and the time-invariant variable Size $_{i}$ drop out of the first-difference model. One consequence is that we cannot formally address the main prediction of the standard model that small countries levy lower tax rates then their larger neighbors. However, the country size enters into the first-difference equation because of the interaction with the slope of the reaction function. Thus we can test the prediction of the extended model that small countries react less intensively to changes in neighbors' tax rates then large countries do. To be in line with the theoretical model, the total effect of a change in neighbors' tax rate, i.e. $\beta+\delta \cdot$ Size $_{i}$ should be positive and should increase with country size, i.e. $\delta>0$.

Following from the assumption that the tax rates in different countries are jointly determined, the neighbor's tax rate and the interaction term in Eq. (9) must be treated as endogenous. I address the endogeneity problem in three ways. First, first differencing takes care of unobserved time-invariant variables. Second, I use the lagged values of the neighbors' taxes. Third, I estimate (9) using the spatial two stage least squares (2SLS) procedure outlined in Kelejian and Prucha (1998). Under this procedure, the neighbors' exogenous explanatory variables are used to instrument for the neighbors' tax rate. In the first stage I estimate two reduced form equations, one for the neighbor's tax rate and one for the interaction term, regressing the endogenous variable on the weighted average of the neighbors' covariates $\left(\Delta \sum_{j \neq i} \omega_{i j} X_{j t-1}\right)$ as well as its interaction with size $\left(\sum_{j \neq i} \omega_{i j} X_{j t-1} \cdot S i z e_{i}\right)$. For this procedure to yield consistent estimates, the neighbors' covariates used as instruments should not be correlated with the error term. This condition is unlikely to hold for macroeconomic covariates, since the neighbors' economic conditions are likely to be correlated with unobserved country characteristics. As a result, I follow a more conservative approach and use the neighbors' political covariates to instrument for the neighbors tax rate as it is more plausible to assume that a neighboring country's political covariates are exogenous to the home country's tax rate. The political variables that I consider as potential instruments are: the party composition of governments and election and post-election year dummies. In order to strengthen the 
instruments, I add the weighted average tax of the neighbors' neighbors as additional instrument following the method used in Altshuler and Goodspeed (2003) and also in Egger at al. (2005). As argued by Altshuler and Goodspeed (2003), the tax rate of the neighbors of the neighbors of country i should be correlated with the tax rate of the neighbors of country $i$, but uncorrelated with the tax rate of country i.4 The two sets of instruments are sufficiently strong together but not separately. However, when entered separately, they yield the same qualitative conclusions. 5

\subsection{THE WEIGHTING SCHEME}

If a country has more than one neighbor (competitor), the value of the neighbors' tax rate is calculated as the weighted average of the neighbor countries' tax rates. This procedure is widely used in the literature and enables us to keep the parameters to be estimated within reasonable limits. The construction of weights starts with determining which countries are in competition with one another. Since cross-border shopping typically takes place between contiguous countries, it is plausible to assume that countries typically view only their geographical neighbors as competitors. Next we have to determine the relative importance of each of these competitors in influencing the taxation decision of a particular country. A country should rationally pay more attention to those of its neighbors whose actions exert a larger influence on its tax base. An optimal weighting scheme should take that into account. The length of border, the number of border crossings and the size of population living close to the border are variables that likely to play important roles. Indeed, the most frequently used weighting schemes in the literature are ones based on spatial criteria. The potential for crossborder shopping may also depend on the traffic flow generated by holiday and business trips and trips undertaken by road haulers. Road haulers are expected to have an especially strong incentive to exploit international fuel price differences given that their fuel bill accounts for 15 to 30 percent of their total operating costs. In case of diesel most cross-border purchases are likely to be made by commercial carriers and this suggests the construction of a weighting scheme that is based on cross-border commercial traffic. In the suggested weighting scheme, weights are dependent on the volume of heavy motor vehicle traffic at common border crossings:

\footnotetext{
4 To understand the intuition, consider the example of Portugal. For Portugal we have to instrument the tax rate of Spain. We do this by using the tax rate in France. This instrument should be valid because France is a neighbor to Spain, but is not a neighbor to Portugal, and hence our theory both predicts that its tax does depend on the tax of the latter, but it does not on the tax of the former. (Note that the neighbors' neighbors rate for a country $i$ is a weighted average of taxes of those countries that are neighbors to the neighbors of country $i$, but not neighbors to country i.)

5 The results are available upon request.
} 
$\omega_{i j}=\left\{\begin{array}{lll}h_{i j} / \sum_{j \in N_{i}} h_{i j} & \text { if } & j \in N_{i} \\ 0 & \text { if } & j \notin N_{i}\end{array}\right.$

where $h_{i j}$ is the annual average daily traffic by heavy trucks at the border of country $i$ and country $j .6$ I will refer to this scheme as traffic flow weights from now on. Using these weights I essentially assume that neighboring countries compete primarily for the diesel purchases by truck and bus drivers.

One problem in implementing (10) is how to handle direct traffic between two countries being separated only by see. For example, a large number of trucks travel between Sweden and Denmark without passing through a third country using ferry services. Since these vehicles constitute a potential for exploiting fuel price differences between these two countries, I treated Sweden and Denmark as neighbors to each others and considered the volume of traffic flow between them in calculating (10). For similar reasons, direct freight traffic flows between the United Kingdom on the one hand and France, Belgium and the Netherlands on the other were also considered in computing (10).

Another question is whether the weights are exogenous themselves. While traffic flows may be endogenous on the long run with respect to diesel excise taxes, they are likely to be predetermined in the short run. As a robustness check, however, I will consider two alternative weighting schemes in section 4 .

\subsection{DATA AND VARIABLES}

I constructed a balanced panel of data from 16 Western European countries - the old EU-15 without Greece but including Norway and Switzerland - between the period of 1978 to 2005 . Greece has been left out because it has no common border with any of the former EU member states.

\section{Dependent variable}

The data on diesel tax rates are collected from the International Energy Agency's Energy Prices and Taxes database. This database provides information about prices and taxes for automotive diesel from 1978 onwards. As a measure for the diesel tax, I take excise levels, expressed in current EUR per liter (current ECU per liter before 1999). VAT is not included,

\footnotetext{
${ }^{6}$ The data on heavy vehicle motor traffic were taken from the UNECE's 2000 Combined Census of Motor Traffic and Inventory of Standards and Parameters on Main International Traffic Arteries in Europe (UNECE 2003).
} 
because it is reimbursed to commercial users irrespective of the location of purchase, i.e. whether it is home or abroad. In a recent paper, Evers et al. (2004) use the tax ratio defined as a ratio of the excise and the price (inclusive of excises) to investigate tax competition in diesel excises among EU countries. I prefer the use of statutory tax rates over tax ratios for two compelling reasons. First, while the level of statutory rate in a country is exclusively decided by the government, tax ratios include the producer price of diesel which governments have no control over. Second, the producer price of diesel in every European country follows the world price of crude oil, implying that tax ratios are correlated across countries due to common oil price shocks. This means that for this tax variable it is more difficult to convincingly demonstrate that the interdependence of national tax polices is attributable to true strategic interactions and is not driven by common shocks.

\section{Country size}

My second key variable is country size. I use two alternative variables to measure the size of a country: its total surface area (in square kilometers) and the value of its gross domestic product in the mid-year of the sample. The first variable measures a country's spatial extension, while the second captures the size of its economy. The former variable is consistent with the theoretical model in Nielsen (2001) (as well as the one in this paper) while the latter corresponds to the model in Kanbur and Keen (1993). Previous empirical studies tend to use an absolute measure of country size, with the exception of Egger et al. (2005) and Jacobs et al. (2007) who use both domestic country size and the weighted country size of neighbors as explanatory variables. Since I estimate the model in first differences I prefer to measure country size in relative terms. The relative country size variable is computed as a ratio of domestic country size to the weighted country size of neighbors. The latter is calculated using the same weights as those used to average the taxes of neighbors $\left(\omega_{i j}\right)$.

\section{Control variables}

I control for a number of other factors that may explain differences in excise tax rates across time and countries. I introduce two dummy variables controlling for the effect of electoral cycles: an election and post-election year dummy variables. To account for the possibility that left-wing and right-wing governments pursue different economic policies I add an index that 
measures the party composition of governments. 7 The second set of explanatory variables focuses on the differences in fiscal conditions across countries. They include: public debt and budget deficit (both variables are measured as a percentage of GDP). Because these variables are potentially endogenous, they are predetermined. Finally, I control for economic development by including a measure of per capita GDP. I hypothesize a positive relationship between the level of diesel excise taxes and economic development on the basis that countries with more developed economies have to spend more on road infrastructure to meet their growing demands of road transport. Finally, I use a set of year dummies to control for unobserved influences common to all countries in a given year. The year dummies also pick up changes in the minimum excise rate for diesel. (The EU's minimum tax rate policy will be discussed in more detail in session 5.)

The development of diesel excise over the last three decades

In Figure 2, I divided the sample into two country groups on the basis of median country size. ${ }^{8}$ The figure shows the evolution of the average petrol excises separately in the groups of large and small countries between 1978 and 2005. It can be seen that excise tax rates paid by diesel consumers have risen substantially in nominal terms over the last three decades. From its initial average level of 8 eurocent per liter it grew to an average of 34-35 eurocent per liter in the group of small countries and to an average of 43-44 eurocent per liter in the group of large countries. The figure also shows that the average tax rate levied by small countries did not significantly differ from the one levied by large countries in the period 1978-1994. However, this pattern has changed greatly over the past ten years. Since 1995, small countries levy significantly lower diesel taxes than large countries do, which has led to a substantial tax gap between small and large countries. This gap continued to widen in the years between 1995 and 2000, then, subsequent to the increase in the EU's minimum tax rate, it narrowed a bit in 2004/5. In summary, the tax setting behavior of national government in Europe seems to be consistent only with the asymmetric tax competition model in the period 1995-2005.

\footnotetext{
7 The index for the party composition of governments is based on the Schmidt index, which is scaled from 1 to 5 . It takes on 1 when the government contains only right-wing parties; 2 when the share of left-wing parties is less than 33\%; 3 when the share of left-wing parties is less than 66\%; 4 when the share of left-wing parties is more than 66\%; 5 when all coalitional parties are left-wing.

8 I find that both of my country size variables result in the same country ranking by size. Finland, France, Germany, Italy, Norway, Spain, Sweden, and the United Kingdom are specified as large countries, while Austria, Belgium, Denmark, Ireland, Luxembourg, the Netherlands, Portugal and Switzerland are specified as small countries.
} 


\section{Development of diesel excises in the large and the small countries EUR/liter (current values)}

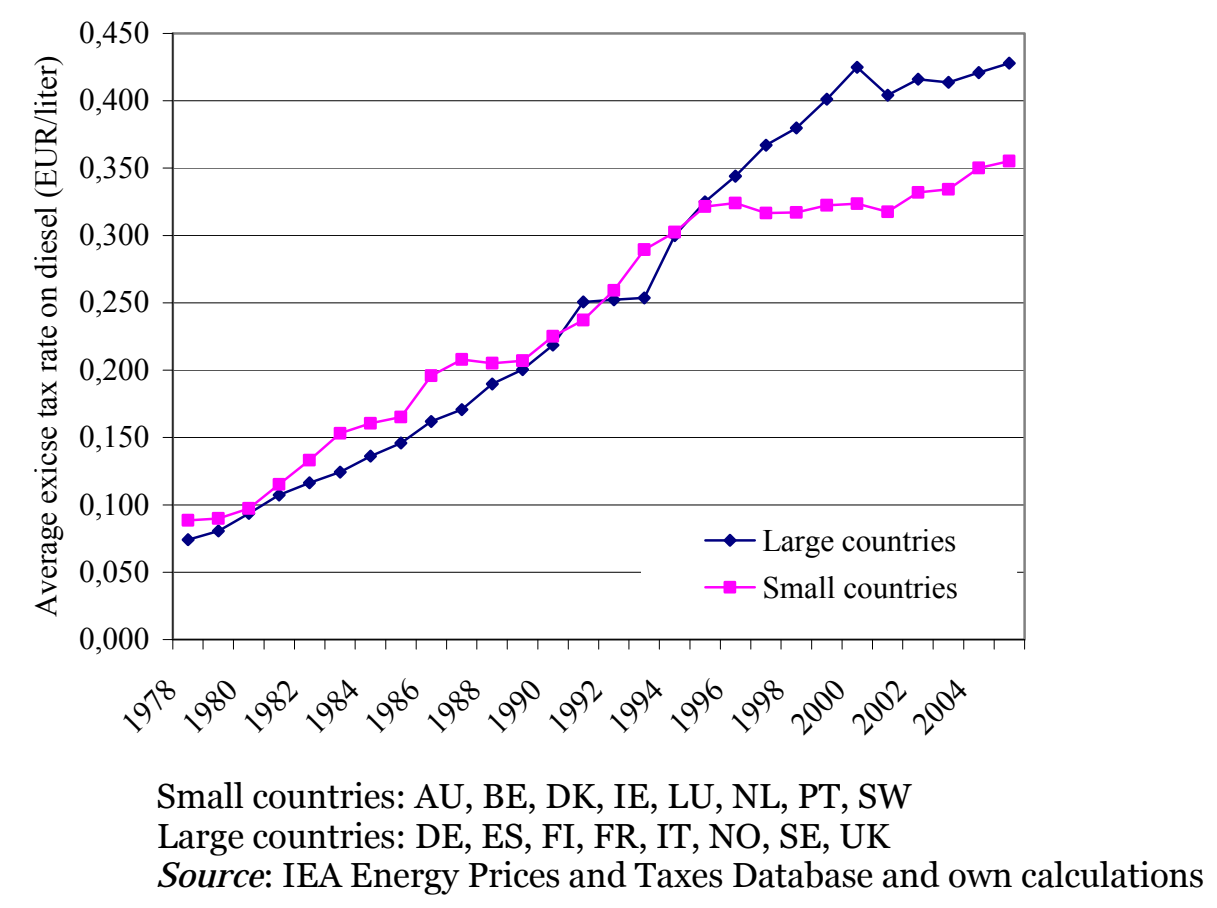

\section{RESULTS}

Table 1 reports the results of the estimation of Eq. (9) using my traffic flow weights. There are four columns of results: in the first two, the country size variable is based on surface area (measured as the ratio of the home country's surface area to the weighted surface area of its neighbors), and in column 3 and 4 the surface-based measure of country size is replaced by its GDP-based equivalent. Each pair of columns includes first an OLS model (for purpose of comparison) and then a 2SLS model to account for the possibility that the neighbors' tax rate is endogenous. In all cases I correct for serial correlation by using AR(1) term. The presence of the interaction term in the equation implies that the marginal effect of the neighbors' tax rate depends on the size of the country. I calculated the marginal effects at the median values of country size and reported them in the lower part of the table. 
Estimates for diesel excise taxes (1978-2005)

\begin{tabular}{|c|c|c|c|c|}
\hline Estimation method: & OLS & 2SLS & OLS & 2 SLS \\
\hline Change in neighbors' tax (t-1) & $\begin{array}{c}-0.169 \\
(-1.231)\end{array}$ & $\begin{array}{c}0.083 \\
(0.248)\end{array}$ & $\begin{array}{c}-0.133 \\
(-1.048)\end{array}$ & $\begin{array}{c}0.143 \\
(0.486)\end{array}$ \\
\hline Change in neighbors' tax $(\mathrm{t}-1) *$ Surface & $\begin{array}{c}0.019 * * * \\
(3.078)\end{array}$ & $\begin{array}{c}0.031 * * * \\
(2.797)\end{array}$ & & \\
\hline Change in neighbors' tax (t-1)*GDP & & & $\begin{array}{c}0.018 * * \\
(2.436)\end{array}$ & $\begin{array}{c}0.029 * * * \\
(4.411)\end{array}$ \\
\hline Change in leftist/conservative government & $\begin{array}{l}0.032 * * \\
(2.581)\end{array}$ & $\begin{array}{c}0.036 * * * \\
(2.806)\end{array}$ & $\begin{array}{l}0.032 * * \\
(2.584)\end{array}$ & $\begin{array}{c}0.036 * * * \\
(2.951)\end{array}$ \\
\hline Election year dummy & $\begin{array}{c}-0.022 \\
(-0.910)\end{array}$ & $\begin{array}{c}-0.023 \\
(-0.979)\end{array}$ & $\begin{array}{c}-0.024 \\
(-1.033)\end{array}$ & $\begin{array}{c}-0.027 \\
(-1.170)\end{array}$ \\
\hline Post-election year dummy & $\begin{array}{c}-0.017 \\
(-0.771)\end{array}$ & $\begin{array}{c}-0.016 \\
(-0.458)\end{array}$ & $\begin{array}{c}-0.018 \\
(-0.802)\end{array}$ & $\begin{array}{c}-0.018 \\
(-0.514)\end{array}$ \\
\hline Change in government debt $(\mathrm{t}-1)$ & $\begin{array}{c}-0.038 \\
(-0.610)\end{array}$ & $\begin{array}{c}0.027 \\
(0.397)\end{array}$ & $\begin{array}{c}-0.037 \\
(-0.589)\end{array}$ & $\begin{array}{c}0.028 \\
(0.424)\end{array}$ \\
\hline Change in government deficit (t-1) & $\begin{array}{c}-0.016 * * \\
(-2.373)\end{array}$ & $\begin{array}{l}-0.019 * * \\
(-2.252)\end{array}$ & $\begin{array}{c}-0.015^{* *} \\
(-2.256)\end{array}$ & $\begin{array}{c}-0.018 * * \\
(-2.149)\end{array}$ \\
\hline Change in GDP per capita & $\begin{array}{c}1.153 * * * \\
(4.537)\end{array}$ & $\begin{array}{c}1.007 * * * \\
(4.259)\end{array}$ & $\begin{array}{c}1.157 * * * \\
(4.480)\end{array}$ & $\begin{array}{c}1.008 * * * \\
(4.170)\end{array}$ \\
\hline $\operatorname{AR}(1)$ & $\begin{array}{c}0.381 * * * \\
(5.147)\end{array}$ & $\begin{array}{c}0.345^{* * *} \\
(5.227)\end{array}$ & $\begin{array}{c}0.381 * * * \\
(5.222)\end{array}$ & $\begin{array}{c}0.341 * * * \\
(5.377)\end{array}$ \\
\hline Year dummies & yes & yes & yes & yes \\
\hline $\mathrm{R}^{2}$ & 0.326 & 0.274 & 0.326 & 0.276 \\
\hline No. of observations & 400 & 400 & 400 & 400 \\
\hline Marginal effect & $\begin{array}{c}-0.073 * * * \\
(5.63)\end{array}$ & $\begin{array}{c}0.240 * * * \\
(14.95)\end{array}$ & $\begin{array}{c}-0.059 * * \\
(3.03)\end{array}$ & $\begin{array}{c}0.263 * * * \\
(15.32)\end{array}$ \\
\hline Excluded instruments I: $\mathrm{F}(D F 1 ; D F 2)$ & & $16.19 * * *(4 ; 364)$ & & $20.42 * * *(4 ; 364)$ \\
\hline Excluded instruments II: F (DF1;DF2) & & $17.05 * * *(4 ; 364)$ & & $23.67 * * *(4 ; 364)$ \\
\hline Sargan test: $\chi^{2}(D F)$ & & $0.10(2)$ & & $0.22(2)$ \\
\hline
\end{tabular}

Notes: Dependent variable is the change in excise tax rate on diesel;

$\mathrm{t}$-statistics, $\mathrm{F}$-statistics and degrees of freedom of $\mathrm{F}$ and $\chi^{2}$ tests are in parenthesis;

* significant at $10 \%,{ }^{* *}$ significant at $5 \%,{ }^{* * *}$ significant at $1 \%$ (statistical significance of the coefficients is calculated using White period system robust errors);

Neighbors' tax rate is calculated using traffic flow weights.

"Marginal effect" is the marginal effect of a change in neighbors' tax rate evaluated at the median level of country size variable (surface or GDP);

Instruments used in IV regression are described in text.

The key variables of interest are the neighbors' tax rate and the interaction term. The coefficient of the interaction term is statistically significant and of positive value in all models presented in Table 1. The coefficients of the neighbors' tax rate are negative in the OLS models and positive in the 2SLS models, but they are not significantly different from zero. Based on the OLS estimates, the marginal effect of a change in neighbors' tax rate evaluated at the median value of country size is negative and small in magnitude for both measures of country size. If estimated by 2 SLS, the estimated marginal effects become positive and moderately strong as well as statistically significant. The results, which are remarkably similar across the 
two measures, indicate that in a median-size country a 10 percent increase in the neighboring countries' tax rates induces about a 2.5 percent increase in its own tax rate. These results confirm the presence of tax competition between EU countries in the setting of diesel excise taxes (Hypothesis 1).

Several of my control variables also show significant effects on diesel excise tax rates. The statistically significant positive coefficient on party composition of governments indicates that governments controlled by left-wing parties are more likely to increase diesel taxes. Government budget balance is found to have a negative impact, suggesting that higher budget deficit is eventually followed by higher diesel taxes. Finally, richer countries tend to levy higher diesel tax rates as indicated by the statistically significant and positive coefficient on per capita GDP.

The main contribution of this paper is to explore the impact of country size on strategic interactions. The significantly positive interaction terms in the 2SLS models confirm my principal theoretical prediction that large countries respond more to changes in their neighbors' tax rate than small countries do (Hypothesis 3). To illustrate the importance of country size in influencing the slope of the reaction function I computed the marginal effect of neighbors' tax rate at the lower and upper quartile country sizes of the sample based on the coefficient estimates in Table 1. These calculations are presented in Table 3. We find that for the surface-based measure of country size the marginal effect of the neighbors' tax is 0,463 when evaluated at the upper quartile and 0.130 when evaluated at the lower quartile. The same figures for the GDP-based country size measure are 0.637 and 0.182 , respectively. These estimates show that the reaction of an "average" large country (i.e. a country with upper quartile territory) to changes in their neighbors' tax rates is more than three times greater than that of an "average" small country (i.e. a country with lower quartile territory). These results confirm that country sizes have a strong impact on the slope of the reaction functions for diesel excise taxes. While this finding is in agreement with my tax competition model allowing for price elastic individual demand it is in strong contradiction to the standard model based on inelastic demand. This shows that ignoring the possibility that the reaction of countries may differ according to their size may lead to strong empirical biases which underlines the importance of my theoretical extension.

As shown in Figure 2, the data between 1995 and 2005 are consistent with Hypothesis 2: small-sized European countries tend to levy lower excise tax rates on diesel than large-sized countries do in this period. Since Hypothesis 2 and 3 are derived from and consistent with the same theoretical model, the confirmation of Hypothesis 3 can be taken as an indirect evidence for Hypothesis 2. That is, it appears that the forces of tax competition that drive small European countries to undercut their larger neighbors. Nevertheless, as Hypothesis 2 seems to hold only from 1995, this may reflect that diesel excise tax competition between EU countries 
has intensified over the last ten years of the sample period. To test this hypothesis formally now I run the same regressions of Table 1 for the period before and after 1994. The results are reported in Table 2. For brevity, I only report the results from the instrumental variable estimations.

Table 2

\section{SLS estimates for diesel excise taxes, separately}

for 1978-1994 and for $1995-2005$

\begin{tabular}{|c|c|c|c|c|}
\hline \multirow{2}{*}{$\begin{array}{l}\text { Period: } \\
\text { Change in neighbors' tax (t-1) }\end{array}$} & \multicolumn{2}{|c|}{$1978-94$} & \multicolumn{2}{|c|}{$1995-05$} \\
\hline & $\begin{array}{c}0.020 \\
(0.090)\end{array}$ & $\begin{array}{c}0.114 \\
(0.431)\end{array}$ & $\begin{array}{c}0.167 \\
(0.423)\end{array}$ & $\begin{array}{c}0.152 \\
(0.415)\end{array}$ \\
\hline Change in neighbors' tax $(\mathrm{t}-1) *$ Surface & $\begin{array}{c}0.026^{* *} \\
(2.108)\end{array}$ & & $\begin{array}{c}0.039 * * \\
(2.489)\end{array}$ & \\
\hline Change in neighbors' tax $(\mathrm{t}-1) * \mathrm{GDP}$ & & $\begin{array}{c}0.017 \\
(1.471)\end{array}$ & & $\begin{array}{c}0.056^{* *} \\
(2.163)\end{array}$ \\
\hline Change in leftist/conservative government & $\begin{array}{c}0.046 * * * \\
(3.643)\end{array}$ & $\begin{array}{c}0.044 * * * \\
(3.283)\end{array}$ & $\begin{array}{c}0.045 * * \\
(2.121)\end{array}$ & $\begin{array}{c}0.043 * * \\
(2.236)\end{array}$ \\
\hline Election year dummy & $\begin{array}{c}-0.050 \\
(-1.221)\end{array}$ & $\begin{array}{c}-0.051 \\
(-1.285)\end{array}$ & $\begin{array}{c}-0.009 \\
(-0.206)\end{array}$ & $\begin{array}{c}-0.018 \\
(-0.449)\end{array}$ \\
\hline Post-election year dummy & $\begin{array}{c}-0.026 \\
(-0.491)\end{array}$ & $\begin{array}{c}-0.029 \\
(-0.559)\end{array}$ & $\begin{array}{c}0.014 \\
(0.395)\end{array}$ & $\begin{array}{c}0.025 \\
(0.746)\end{array}$ \\
\hline Change in government debt $(\mathrm{t}-1)$ & $\begin{array}{c}0.078 \\
(1.284)\end{array}$ & $\begin{array}{c}0.079 \\
(1.215)\end{array}$ & $\begin{array}{c}0.001 \\
(0.008)\end{array}$ & $\begin{array}{c}-0.034 \\
(-0.337)\end{array}$ \\
\hline Change in government deficit (t-1) & $\begin{array}{c}-0.008 \\
(-0.788)\end{array}$ & $\begin{array}{c}-0.007 \\
(-0.683)\end{array}$ & $\begin{array}{l}-0.041^{*} \\
(-1.918)\end{array}$ & $\begin{array}{l}-0.039 * \\
(-1.889)\end{array}$ \\
\hline Change in GDP per capita & $\begin{array}{c}1.229 * * * \\
(5.937)\end{array}$ & $\begin{array}{c}1.202 * * * \\
(5.585)\end{array}$ & $\begin{array}{c}0.883 * * * \\
(2.615)\end{array}$ & $\begin{array}{c}0.921 * * * \\
(2.630)\end{array}$ \\
\hline $\operatorname{AR}(1)$ & $\begin{array}{c}0.425 * * * \\
(3.676)\end{array}$ & $\begin{array}{c}0.403 * * * \\
(3.717)\end{array}$ & $\begin{array}{c}0.399 * * * \\
(2.995)\end{array}$ & $\begin{array}{c}0.400 * * * \\
(3.192)\end{array}$ \\
\hline Year dummies & yes & yes & yes & yes \\
\hline $\mathrm{R}^{2}$ & 0.274 & 0.268 & 0.224 & 0.257 \\
\hline No. of observations & 224 & 224 & 160 & 160 \\
\hline Marginal effect & $\begin{array}{c}0.151^{*} \\
(2.41) \\
\end{array}$ & $\begin{array}{l}0.184 \\
(1.20) \\
\end{array}$ & $\begin{array}{c}0.364 * * * \\
(5.92) \\
\end{array}$ & $\begin{array}{c}0.383 * * * \\
(3.20) \\
\end{array}$ \\
\hline Excluded instruments I: $\mathrm{F}(D F 1 ; D F 2)$ & $5.87 * * *(4 ; 199)$ & $6.55 * * *(4 ; 199)$ & $5.75 * * *(6 ; 153)$ & $4.58 * * *(6 ; 153)$ \\
\hline Excluded instruments II: F (DF1;DF2) & $8.94 * * *(4 ; 199)$ & $2.96 * *(4 ; 199)$ & $7.17 * * *(6 ; 153)$ & $11.76 * * *(6 ; 153)$ \\
\hline Sargan test: $\chi^{2}(D F)$ & $0.22(2)$ & $0.40(2)$ & $3.81(4)$ & $1.89(4)$ \\
\hline
\end{tabular}

Notes: Dependent variable is the change in excise tax rate on diesel;

$\mathrm{t}$-statistics, F-statistics and degrees of freedom of $\mathrm{F}$ and $\mathrm{\chi}^{2}$ tests are in parenthesis;

${ }^{*}$ significant at $10 \%,{ }^{* *}$ significant at $5 \%,{ }^{* * *}$ significant at $1 \%$ (statistical significance of the coefficients is calculated using White period system robust errors);

Neighbors' tax rate is calculated using traffic flow weights.

"Marginal effect" is the marginal effect of a change in neighbors' tax rate evaluated at the median level of country size variable (surface or GDP);

Instruments used are described in text. 
The regression results in Table 2 are consistent with the findings in Figure 2. First, we observe that there is less evidence of tax competition between EU countries before 1995 than after. In the regressions for the period 1978-1994, the neighbors' tax rate and the interaction term are jointly significant at 10 percent level for the surface-based country size variable, but statistically insignificant for the alternative measure. Similarly, the interaction term is found to have statistically significant impact only for the surface-based measure of country size. On the other hand, we find robust evidence of tax competition for the subperiod 1995-2005. In both regression models, the neighbors' tax rate and the interaction term are jointly significant with the interaction term being individually significant at 5 percent level. Second, my results also indicate that tax competition plays a much more important role after 1995. Note that the regression for the subperiod 1995-2005 yields higher parameter estimates for both the neighbors' tax rate and the interaction variables in both models. Before 1995, for example, the coefficient on the interaction term is 0.026 but, after 1995, it is 0.039 for the surface-based measure of country size. The higher coefficient estimates imply that the importance of tax competition grows markedly after 1995. After 1995, the slope of the reaction function of the median sized country is 0.364 , which is more than double the value obtained for the period before 1995 considering the specifications with the surface-based country size variable. The same pattern emerges when the GDP-based size variable is included.

The above result comes as no surprise. The mid 1990s was a very important phase in the EU integration process. By this time, with the abolition of internal borders and the introduction of common currency, the EU has removed most of the restrictions on consumer movements between member states. The late 1990 s have also witnessed the liberalization of the road haulage market, which has led to a strong price competition and boosted international transport. These changes must have increased the sensitivity of European consumers and transport companies to international fuel price differences, which then set the stage for a more intense tax competition between EU countries.

Table 3

\section{Marginal effect of neighbors' tax rate at different levels of country size (surface or GDP)}

\begin{tabular}{|c|c|c|c|c|c|c|}
\hline & \multicolumn{2}{|c|}{ 1978-2005 } & \multicolumn{2}{|c|}{ 1978-1994 } & \multicolumn{2}{|c|}{$1995-2005$} \\
\hline & Surface & GDP & Surface & GDP & Surface & GDP \\
\hline Lower quartile & 0.130 & 0.182 & 0.060 & 0.137 & 0.227 & 0.227 \\
\hline Median & 0.240 & 0.263 & 0.151 & 0.184 & 0.364 & 0.383 \\
\hline Upper quartile & 0.436 & 0.637 & 0.316 & 0.404 & 0.611 & 1.106 \\
\hline
\end{tabular}

Notes: The results are based on the 2SLS estimates reported in Table 1-2. 
So far I have weighted foreign tax rates using my traffic flow weights. The traffic flow weights were based on the assumption that governments determine the importance of each of their neighbors based on the volume of cross-border commercial traffic from and to these neighbors. This seems to be reasonable since in the case of diesel most cross-border purchases are made by commercial carriers and borders being crossed by more commercial vehicles are likely to create more opportunities for cross-border shopping. Now I explore the sensitivity of results to using different weighting schemes. I consider two commonly used schemes for this purpose. The first is the border weighting scheme, which defines potential competitors as a country's common-border neighbors and treats all common-border neighbors equally. To allow for a more direct comparison between border weights and my traffic flow weights, my border weights apply the same definition of competitors as the traffic flow weights. That is, it allows for a larger group of competitors than common-border neighbors for the UK and Sweden (see section 3.2), but it continues to attach equal weight to each country identified as competitor.

Second, I re-estimate my baseline specification using the alphabetical weights outlined in Case et al. (1993). The alphabetical weights are constructed using a "nonsense" procedure; a country is considered as neighbor or competitor if it comes before or after the other country in the alphabet (e.g., Austria has the United Kingdom and Belgium for competitors). The analysis with the alphabetical weights serves as a general robustness check on my basic findings. If my above results are merely picking up a common trend in national tax policies than it should not really matter how we define competitors; i.e. we should observe the same effects for any weighting scheme including the alphabetical weights. On the other hand, if the correlation of national tax rates is indeed driven by tax competition then nonsensical weighting schemes should provide no evidence of strategic interactions.

Table 4

\section{SLS estimates for diesel excise taxes with other weighting schemes (1978-2005)}

\begin{tabular}{lcccc}
\hline \hline Weighting scheme & $\begin{array}{c}\text { Country } \\
\text { size }\end{array}$ & $\begin{array}{c}\text { Change in neighbors' tax } \\
(\mathrm{t}-1)\end{array}$ & $\begin{array}{c}\text { Change in neighbors' tax } \\
(\mathrm{t}-1) * \text { Country size }\end{array}$ & Marginal effect \\
\hline \multirow{2}{*}{ Border weights } & Surface & $0.009(0.031)$ & $0.033^{* * *}(2.876)$ & $0.176^{* * *}(7.62)$ \\
& GDP & $0.055(0.206)$ & $0.028^{* * *(3.677)}$ & $0.170^{* * *(9.02)}$ \\
Alphabetical weights & Surface & $-0.109(-0.660)$ & $-0.011(-0.940)$ & $-0.165(0.87)$ \\
& GDP & $-0.074(-0.463)$ & $-0.011(-1.076)$ & $-0.119(0.80)$ \\
\hline \hline
\end{tabular}

Notes: Dependent variable is the change in excise tax rate on diesel;

Every regression was performed including all other explanatory variables used in previous estimations (see Table 1);

t-statistics and F-statistics are in parenthesis;

${ }^{*}$ significant at $10 \%,{ }^{* *}$ significant at $5 \%,{ }^{* * *}$ significant at $1 \%$, statistical significance of the coefficients is calculated using White period system robust errors; 
"Marginal effect" is the marginal effect of a change in neighbors' tax rate evaluated at the median level of country size variable (surface or GDP);

Instruments used are described in text.

Table 4 presents the results for the two new weighting schemes. As in Table 1, I estimated the model separately for the surface- and GDP-based variables of country size. For brevity, I only report the 2 SLS estimates of the parameters of interest (i.e. the neighbors' tax rate and the interaction term) and the size of the slope parameter for the median size country. The findings in Table 4 can be summarized as follows. First, using the border weights instead of the traffic flow weights does not change the main conclusions of the analysis. The effect of tax competition is statistically significant and, as evaluated at the median country size, is large in magnitude in both specifications. The statistically significant positive interaction terms also confirm the role of country size in determining the strength of tax responses. Second, the economic importance of tax competition diminishes somewhat when the border weights are used. The estimated slope parameter for the median size country ranges between 0.170 and 0.176, which is about 30 percent less than what was found for the traffic flow weights. The impact of country size is also weaker as indicated by the smaller coefficient on the interactions term. Since the traffic flow weights more closely reflect the possibility of cross-border shopping by commercial carriers, its better performance supports the notion that national governments compete for the fuel purchases of commercial carriers in setting their diesel excise tax rates. Third, the alphabetical weights provide no evidence of tax competition. The coefficients of the two variables are of the wrong sign, but they are neither individually nor jointly statistically significant. This is additional evidence that my primary results are not an artifact of the data.

\section{THE MINIMUM TAX RATE}

In 1993, the European Union has introduced a system of minimum tax levels for the excise duties on alcoholic drinks, cigarettes and mineral oils (including automotive diesel). This means that the EU member states may not apply lower excise rates on these excisables than the specified minimum rates. At the outset, the minimum excise duty rate on diesel was 0.254 EUR/liter, which was increased to 0.302 EUR/liter in 2004.

It was expected that the minimum tax rate would narrow the tax band across member states and thereby it will reduce the incentive for cross-border shopping and tax competition. In the context of diesel excises it would therefore be interesting to examine the extent (if any) to which the introduction of the minimum rate has limited tax competition between EU countries. Unfortunately, the data does not allow me to formally address this issue. I cannot identify the effect of the minimum tax rate on tax competition separately from the (opposing) 
effect of the Single Market because both measures were introduced in the same year, and the level of the minimum tax rate was unchanged between 1993 and 2003.

My empirical analysis in the previous section has shown that strategic interactions in the setting of diesel excises between EU countries have intensified in the mid 1990s. This suggests that the minimum rate has not been very effective in combating tax competition in the sense that it has, at best, mitigated the effect of closer economic integration. Now I evaluate the EU's tax harmonization measure from a somewhat different perspective. Namely, I analyze the extent to which the minimum rate has achieved its primary objective of harmonizing diesel excises across member states.

The impact of various tax harmonization measures on the outcome of tax competition has been studied intensively in the theoretical literature. Kanbur and Keen (1993) analyzed this issue in a two country model and showed that after introducing a minimum tax rate, which is binding for the small country, the small country adjusts its tax rate to the required minimum level whereas the large country raises its tax rate as well, though to a somewhat lesser extent. This indicates that the minimum tax rate reduces but does not eliminate the tax differentials between the two countries. The finding of Kanbur and Keen (1993) - also confirmed by others (Nielsen, 2001; Ohsawa, 2003) - suggests that the minimum tax rate is not the most appropriate measure to achieve harmonized tax rates when tax competition is asymmetric, and the larger the size differences between countries, the less success it can achieve.

In line with the theoretical prediction, small-sized countries in Europe tend to levy lower excise tax rates on diesel than large-sized countries do. As already shown in Figure 2, this process started in the mid 1990 s and led to a substantial gap in tax rates between large and small countries. Over the period 1995-2005 the average excise tax rate on diesel in the group of small countries was on average 15 percent below the average tax level in the group of large countries. Our interest is to see how this tax competition-induced differentiation of tax rates has affected the overall dispersion of tax rates across member states.

Figure 3 depicts the coefficient of variation of annual tax rates since 1978 separately for the small and large countries' groups as well as for the entire sample. We find that tax differences among EU countries decreased steadily between 1978 and 1994. However, this process of convergence stopped in the mid 1990s and national tax rates started to diverge in 1995. Between 1995 and 2000 the coefficient of variation of annul tax rates among the 16 countries increased from 19 percent to 37 percent and then it started to decline again and stood at 26 percent at the end of the sample period. Further, we find that the source of variation in tax rates has also changed after the reversal of convergence. In consistent with Figure 2, we observe that while before 1995 tax rate dispersion was due almost entirely to variation within groups, since 1995 part of the dispersion has come from variation between groups. In particular, the intensification of tax competition has increases the disparities in tax 
rates between large and small countries, contributing to the increase in the overall dispersion of tax rates across member states. This confirms that in the case of diesel excises asymmetric tax competition between the EU member states played an important role in the reversal of the convergence of tax rates.

All in all, between 1992 (i.e. the year before the introduction of the minimum tax rate) and 2005 the coefficient of variation of excise tax rates on diesel has slightly declined for the entire 16 countries of the sample (from 31 to 26 percent), and slightly increased for the 14 member countries of the European Union (from 24 to 27 percent). Thus, the EU's minimum tax rate has not resulted in more harmonized tax rates across member states. This is in line with the theoretical work of Kanbur and Keen (1993) and confirms the inappropriateness of the minimum tax rate to harmonize tax rates under asymmetric tax competition.

Figure 3

\section{Dispersion of excise tax rates on diesel in European countries}

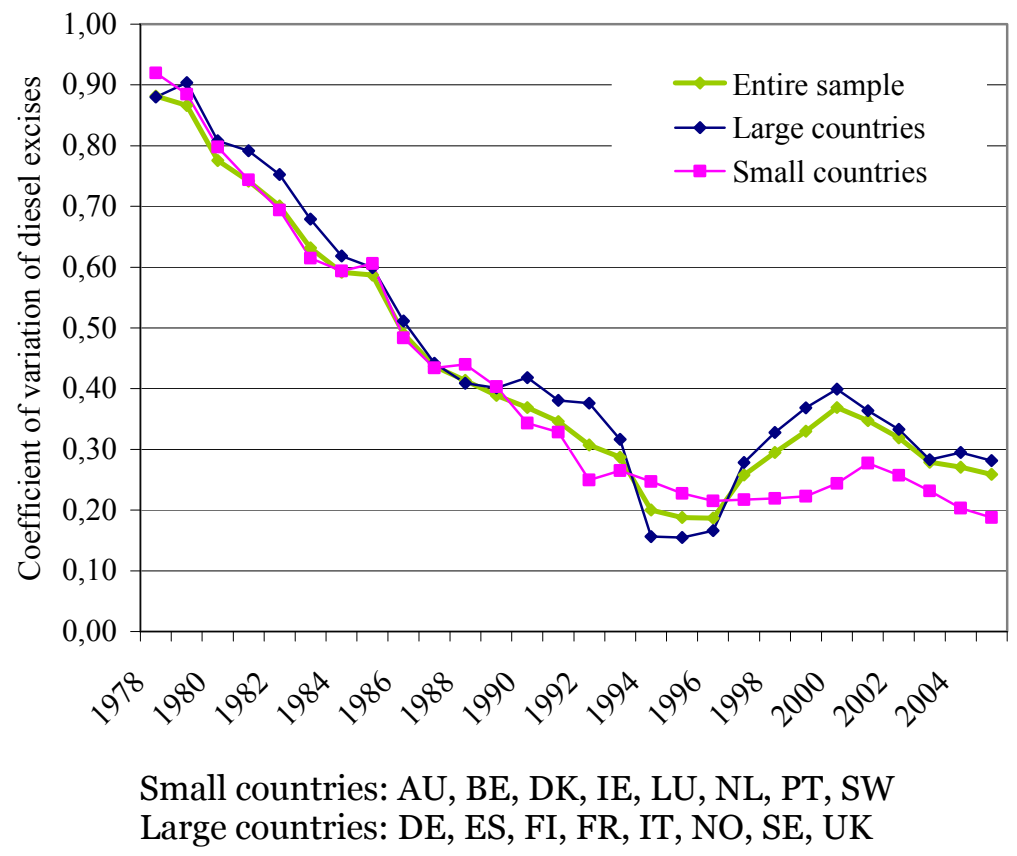

\section{CONCLUSION}

In this work, I extended the standard tax competition model in Nielsen (2001) by replacing the unit demand assumption with iso-elastic demand for the taxed good. I showed that the finding that the small country undercuts the large country in the equilibrium is robust to the introduction of the iso-elastic demand function with elasticity less than 1. More importantly, I demonstrated that the size of reaction induced by a small change in the other country's tax rate 
is different between the two countries. By facing a not completely inelastic tax base, the small country reacts less intensively to changes in the other country's tax rate, compared to the large country.

The theoretical predictions are tested using data on diesel excises from 16 European countries between 1978 and 1995. The regressions are estimated in first differences. I find evidence that European countries compete with each other in setting their diesel excise tax rates. My estimates indicate that in a median size country a 10 percent increase in the neighboring countries' tax rates induces around 2.5 percent increase in its own tax rate. Further, I find evidence that larger country size induces countries to react more aggressively to changes in their neighbors' tax rates. My estimates reveal that the reaction of an average large country to a small change in diesel tax rates in neighboring countries is more than three times greater than that of an average small country. This confirms the principal hypothesis of my paper that under asymmetric tax competition country sizes positively affect not only the level of equilibrium taxes but also the slopes of the tax reaction functions between countries. Finally, there is evidence that strategic interactions between European countries intensified since the mid 1990s.

This paper is most closely related to the work by Lockwood and Migali (2009) and Evers et al. (2004). Lockwood and Migali (2009) investigated the strategic interactions in the setting of four excises (wine, bear, ethyl alcohol and cigarette excises) between 12 EU countries. They find evidence for tax competition in all four excises after 1993 but could confirm the effect of country size on the level of tax rates only in the cases of wine and beer excises. Like me, Evers et al. (2004) investigate tax competition in diesel excise taxes among European countries. They use a database that in addition the 16 countries considered in this paper also contains Greece but only covers the time period from 1978 to 2001. Like me, they estimate the reaction function equation using the first-differences of the data. Despite these similarities my empirical approach differs from theirs in a number of ways, including the measurement of tax burden and country size, the control and instrumental variables used, and the weighting scheme used to aggregate foreign tax rates. Evers et al. analysis also confirms the presence of tax competition in diesel excises over the examined period. However, my results differ from those obtained by Evers et al. in two important ways. Firstly, while I provide strong evidence for asymmetric tax competition between European countries for diesel taxation, they cannot confirm the effect of country size on tax setting. Secondly, while I show that tax competition between EU countries has intensified in the mid 1990s, this issue is not addressed by Evers et al.

The findings in this paper have important policy relevance. As suggested by the theoretical literature, under asymmetric tax competition the minimum tax rate will not result in harmonized tax rates across countries. Thus, the empirical evidence of asymmetric tax 
competition between European countries, provided in this study, explain why the minimum tax policy adopted by the EU in 1993 has failed to narrow the differences in diesel excise levels within the European Union. 
Appendix: Descriptive statistics and data sources

\begin{tabular}{|c|c|c|c|c|c|c|}
\hline \multirow{2}{*}{$\frac{\text { Variable }}{\text { Dependent variable }}$} & \multirow[t]{2}{*}{ Definition } & \multirow[t]{2}{*}{ Source } & \multirow[t]{2}{*}{ Mean } & \multicolumn{2}{|c|}{ Std Dev Min } & \multirow[t]{2}{*}{ Max } \\
\hline & & & & & & \\
\hline Diesel excise tax rate & $\begin{array}{l}\text { Excise tax rate on diesel paid by } \\
\text { commercial users (EUR per liter) }\end{array}$ & IEA: Energy Prices \& Taxes Database & 0.244 & 0.141 & o & 0.796 \\
\hline \multicolumn{7}{|l|}{ Explanatory variables } \\
\hline Neighbors' tax rate & $\begin{array}{l}\text { Average excise tax rate on diesel in } \\
\text { neighboring countries weighted after } \\
\text { traffic flow weights (EUR per liter) }\end{array}$ & $\begin{array}{l}\text { IEA: Energy Prices \& Taxes Database and own } \\
\text { calculations }\end{array}$ & 0.251 & 0.124 & o & 0.796 \\
\hline GDP per capita & $\begin{array}{l}\text { Gross national product divided by } \\
\text { population (EUR per liter) }\end{array}$ & OECD: Economic Outlook Database & 18740 & 10227 & 1825 & 63871 \\
\hline Government debt & $\begin{array}{l}\text { General government debt divided by } \\
\text { GDP }\end{array}$ & OECD: Economic Outlook Database & 58.67 & 29.42 & 4.06 & 140.67 \\
\hline $\begin{array}{l}\text { Leftist/conservative } \\
\text { government }\end{array}$ & $\begin{array}{l}\text { Cabinet composition of government } \\
\text { captured by Schmidt-index, which is } \\
\text { scaled from } 1 \text { (hegemony of right wing } \\
\text { parties) to } 5 \text { (social democratic and } \\
\text { other left parties) }\end{array}$ & $\begin{array}{l}\text { Comparative Political Dataset, Armingeon (2005) } \\
\text { http://ddcn.prowebis.com/study detail.asp?studyid=763 } \\
\text { and Wikipedia }\end{array}$ & 2.56 & 1.42 & 1 & 5 \\
\hline Country size & Total surface area of a country (sq km) & World Bank: World Development Indicators & 217346 & 182242 & 2586 & 551695 \\
\hline
\end{tabular}




\section{REFERENCES}

Altshuler, R., Goodspeed, T. J., 2003. Follow the leader? Evidence on European and U.S. Tax Competition. Draft version, August 14, 2003

Austrian Energy Agency, 2009. Energy Efficiency Polices and Measure in Austria. Available from: http://www.odyssee-indicators.org/publications/PDF/austria_nr.pdf [accessed 4 February 2010]

Case, A.C., Harvey S.R., Hines J.R.J., 1993. Budget Spillovers and Fiscal Policy Interdependence. Journal of Public Economics 52, 285-307.

Commission of the European Communities, 2007. Impact Assessment. COM(2007)52 final SEC(2007)171. (Accompanying document to the Proposal for a Council Directive amending Directive 2003/96/EC.)

Devereux, M.P., Lockwood, B., Redoano, M., 2007. Horizontal and Vertical Indirect Tax Competition: Theory and Some Evidence from the USA. Journal of Public Economics 91, 451-479.

Egger, P., Pfaffermayr, M., Winner, H., 2005. An Unbalanced Spatial Panel Data Approach to US State Tax Competition. Economics Letters 88, 329-335.

Evers, M., Mooij, R.A. de, Vollenbergh, J.R.H., 2004. Tax Competition Under Minimum Rates: The Case of European Diesel Excises. CESifo Working Papers, No. 1221.

Fulton, L., Noland, R., 2005. Pricing and Taxation-Related Policies to Save Oil in the Transport Sector. Energy Prices \& Taxes: Quarterly Statistics, 2005 Edition, International Energy Agency, Paris

International Energy Agency, 2008. Energy Prices and Taxes online Database. IEA, Paris, France.

Jacobs, J.P.A.M., Ligthart, J.E., Vrijburg, H., 2007. Consumption Tax Competition Among Governments: Evidence from the United States. CCSO Working Paper, 07-8 pp. 1-34. Groningen

Kanbur, R., Keen, M. 1993. Jeux Sans Frontiers: Tax Competition and Tax Coordination When Countries Differ in Size. American Economic Review 83, 877-892.

Kelejian, H. H., Prucha, I. R. 1998. A Generalized Spatial Two-Stage Least Squares Procedure for Estimating a Spatial Autoregressive Model with Autoregressive Disturbances. Journal of Real Estate Finance Economics 17, 99-121.

Lockwood, B., Migali, G. 2009. Did the Single Market Cause Competition in Excise Taxes? Evidence from EU countries. The Economic Journal 119, 406-429.

Nielsen, S. B. 2001. A Simple Model of Commodity Taxation and Cross-Border Shopping. Scandinavian Journal of Economics 103, 599-623.

Ohsawa, Y. 2003. A Spatial Tax Harmonization Model. European Economic Review 47, 443459.

UNECE, 2003. 2000 Combined Census of Motor Traffic and Inventory of Standards and Parameters on Main International Traffic Arteries in Europe. United Nations, Genf.

Wilson, J. D., 1991. Tax Competition with Interregional Differences in Factor Endowments, Regional Science and Urban Economics 21, 423-451. 
Discussion Papers published in 2010

Gábor BÉKÉS - Péter HARASZTOSI: Agglomeration Premium and Trading Activity of Firms. MT-DP 2010/1

TARJÁN Tamás: Jánossy elmélete az új növekedéselmélet tükrében. MT-DP. 2010/2

Holger GÖRG - László HALPERN - Balázs MURAKÖZY: Why Do Within Firm-Product Export Prices Differ across Markets? MT-DP. 2010/3

KOZAK Anita - SERES Antal - SZABÓ Márton: Sikeres kisárutermelők és egy sikeres termelési, értékesítési rendszer a zöldség-gyümölcs ágazatban. MT-DP. 2010/4

András SIMONOVITS: Tax morality and progressive wage tax. MT-DP. 2010/5

Peter CZIRAKI - Peter DE GOEIJ - Luc RENNEBOOG: Insider Trading, Option Exercises and Private Benefits of Control. MT-DP. 2010/6

LACKÓ Mária: A rossz magyar egészségi állapot lehetséges magyarázó tényezői; összehasonlító makroelemzés magyar és osztrák adatok alapján, 1960-2004. MT-DP. 2010/7

Gusztáv NEMES: Environmental Governance in Hungary Rural Development Policies and Social Learning during the Implementation of EU Agri-Environmental Policies - A Case Study. MT-DP 2010/8

KOVÁCS Ilona: A hazai jövedelemeloszlás és jövedelemegyenlőtlenség mérése és elemzése személyi jövedelembevallási adatok alapján. MT-DP 2010/9

SERES Antal: A részmunkaidős foglalkoztatás tendenciái és terjedésének tényezői az Európai Unióban és Magyarországon. MT-DP 2010/10

Ilona KOVÁCS: Measuring and analyzing income distribution and income inequality in Hungary based on data from personal income tax returns. MTDP 2010/11

Discussion Papers are available at the website of Institute of Economics Hungarian Academy of Sciences: http://econ.core.hu 